be restricted to hepatocytes in both normal and diseased liver. By immunohistochemistry, no consistent abnormalities in androgen receptor expression were observed in non-neoplastic chronic liver diseases. Interestingly, androgen receptor expression was observed in a significantly greater proportion of women.

Recently Negro et $a l^{10}$ developed a nonradioisotopic in situ hybridisation assay specific for the human androgen receptor mRNA. Although no normal liver was examined, androgen receptor mRNA was detected in eight $(42 \%)$ of 19 non-neoplastic liver specimens, a similar proportion to that found in this study. Androgen receptor mRNA was similarly restricted to hepatocytes, although the proportion of reactive hepatocytes found was noticeably less than in the present study and was never more than $10 \%$. This difference most probably reflects a difference in sensitivity of the two techniques. Indeed, in a test set of frozen sections from five hepatocellular carcinomas (HCCs) stained with a different androgen receptor monoclonal antibody, Negro et al were able to demonstrate androgen receptor protein in only one case, which also expressed androgen receptor mRNA. Two HCCs, strongly positive for the androgen receptor mRNA, were negative by immunohistochemistry and in the remaining two cases, neither androgen receptor protein nor its mRNA could be detected.

Several clinical and experimental observations suggest that drugs which inhibit the activity of sex steroids may control the growth and invasiveness of HCCs in selected patients. However, results of pilot clinical trials have been disappointing so far. ${ }^{3410}$ One explanation for this may be the lack of accurate evaluation of hormonal status prior to any such treatment. The present study has shown the potential of immunohistochemical techniques to demonstrate androgen receptor in liver tissue. We believe that further studies of androgen receptor expression in premalignant lesions, such as small cell dysplasia and atypical macroregenerative nodules, and in hepatocellular carcinoma are now warranted.

We gratefully acknowledge the help of the physicians and surgeons of the Liver Transplant Group, Freeman Hospital Trust for collection of material used in the study. SAH was in receip of a Medical Research Council Clinical Training Fellowship.

1 Okuda K, Ohtsuki T, Obata H. A natural history of hepatocellular carcinoma and prognosis in relation to treatment: study of 850 patients. Cancer 1985;56:918-28.

2 Gleeson D, Newbould MJ, Taylor P, McMahon RF, Leahy BC, Warnes TW. Androgen associated hepatocellular carcinoma with an aggressive course. Gut 1991;32:1084-6.

3 Matsuura B, Taniguchi Y, Oht Y. Effect of anti-androgen treatment on chemical hepatocarcinogenesis in rats. $f$ Hepatol 1994;21:187-93.

4 Guechot J, Peigney N, Ballet F, Vaubourdolle M, Gt-Boudeau J, Poupon R. Effect of D-trytophan-6-luteinizing hormone-releasing hormone on the tumoral growth and plasma sex steroid levels in cirrhotic patients with hepatocellular carcinoma. Hepatology 1989;10:346-8.

5 Kahn D, Gavaler JS, Makowka L, van Thiel DH. Gender of donor influences outcome after orthotopic liver transplantation in adults. Dig Dis Sci 1993;38:1485-8.

6 Isola JJ. Immunohistochemical demonstration of androgen receptor in breast cancer and its relationship to other receptor in breast cancer and its relation

7 Eagon PK, Elm MS, Stafford EA, Porter LE. Androgen receptor in human liver: characterization and quantitation in normal and diseased liver. Hepatology 1994;19:92-100.

8 Ruizeveld de Winter JA, Janssen PJA, Sleddens HMEB Verleun-Mooijman MCT, Trapman J, Brinkmann AO, et al. Androgen receptor status in localised and locally progressive hormone refractory human prostate cancer. Am F Pathol 1994;144:735-46.

9 Zegers ND, Claassen E, Neelen C, Mulder E, van Laar JH, Voorhorst MM, et al. Epitope prediction and confirmation for the human androgen receptor: generation or the human androgen receptor: generation of monoclonal antibodies for multi-assay performance following the synthetic peptide strategy. Biochem Biophys 10 Negro $F$, Papoti

, Pacchioni D, Galami F, Bobino F Bussolati G. Detection of human androgen receptor $\mathrm{mRNA}$ in hepatocellular carcinoma by in situ hybridisation. Liver 1994;14:213-19.

\title{
Alpha-fetoprotein production by a hepatoid adenocarcinoma of the uterus
}

\author{
Department of \\ Obstetrics and \\ Gynecology \\ Hokkaido Úniversity \\ School of Medicine, \\ Kita-15, Nishi-4, \\ Kita-Ku, Sapporo, 060, \\ Japan \\ R Yamamoto \\ M Azuma \\ H Hareyama \\ S Makinoda \\ S Fujimoto \\ Department of \\ Pathology, \\ Hokkaido University \\ School of Medicine \\ H Ishikura \\ Department of \\ Biochemistry, \\ Hokkaido University \\ School of Medicine \\ Y Koyama \\ S Nishi \\ Correspondence to: \\ Dr R Yamamoto. \\ Accepted for publication \\ 18 October 1995
}

\author{
R Yamamoto, H Ishikura, M Azuma, H Hareyama, S Makinoda, Y Koyama, S Nishi, \\ S Fujimoto
}

nosis of embryonal carcinoma or endodermal sinus tumour. The production of AFP by the tumour cells was demonstrated immunohistochemically using the PAP technique. Only two cases of AFP producing endometrial adenocarcinomas have been reported previously.

(f Clin Pathol 1996;49:420-422)

Keywords: alpha-fetoprotein, endometrial adenocarcinoma, hepatoid adenocarcinoma.

Alpha-fetoprotein (AFP) is a fetal serum protein synthesised by fetal liver, yolk sac and gastrointestinal tract. After birth, AFP dis- 




Figure 1 Microscopic findings: a major medullary portion $(A)$ and a minor tubular portion (B).

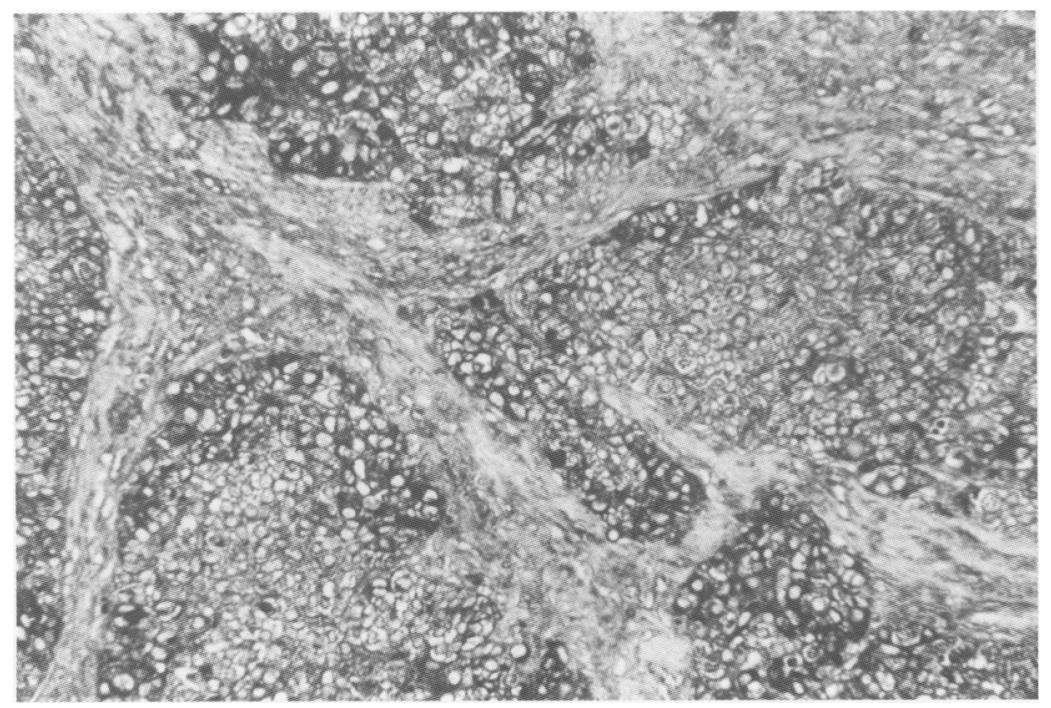

Figure 2 PAP staining for AFP in a surgical specimen. Note the cytoplasmic localisation of $A F P$. puted tomography scan was normal but a few metastatic nodules were found on a chest radiograph. Her serum AFP concentration was raised at $280.3 \mu \mathrm{g} / \mathrm{ml}$. The patient underwent a total abdominal hysterectomy, bilateral salpingo-oophorectomy and liver biopsy in November 1993. On the sixth day after surgery, the patient's serum AFP concentration had fallen to $66.9 \mu \mathrm{g} / \mathrm{ml}$. A course of combination chemotherapy was instituted 10 days after surgery, comprising intraveneous cyclophosphamide $\left(400 \mathrm{mg} / \mathrm{m}^{2} /\right.$ day $)$ and doxorubicin hydrochloride $\left(40 \mathrm{mg} / \mathrm{m}^{2} /\right.$ day $)$ on day 1 and cisplatin $\left(10 \mathrm{mg} / \mathrm{m}^{2} /\right.$ day $)$ for seven consecutive days. This regimen was repeated every three weeks. While on chemotherapy the size and number of lung metastases increased as did her serum AFP concentration (to $935.0 \mu \mathrm{g} / \mathrm{ml}$ by the end of January 1994). The patient died on 15 February 1994. A complete necropsy was carried out.

\section{PATHOLOGY}

The uterus was diffusely enlarged by the extensive tumour invasion into the myometrium and the uterine cavity was filled with a necrotic, haemorrhagic mass. An extensive tumour embolus formation was seen in the right paraovarian area.

Microscopically, the tumour was composed of a major medullary portion and a minor tubular adenocarcinoma which had invaded the myometrium, the myometrial lymphatics and blood vessels. Neoplastic cells in the medullary portion were polygonal with glycogen-rich cytoplasm. Vascular permeation by neoplastic cells was prominent. Extensive hepatoma-like features were observed (fig 1).

AFP expression was detected immunohistochemically in all endometrial adenocarcinoma cells and was particularly strong in the hepatoma-like cells. Formalin fixed, paraffin wax embedded tumour sections were stained by the peroxidase-antiperoxidase (PAP) method using rabbit antiserum directed against $\mathrm{AFP}$, and rabbit antiserum and mouse monoclonal antibody directed against human carcinoembryonic antigen (CEA). Tumour cell cytoplasm was AFP positive (fig 2). In the hepatoma-like cells complex canalicular structures were seen which reacted with the polyclonal (but not the monoclonal) antibody directed against CEA. The necropsy revealed a widespread metastatic proliferation in the lungs.

\section{Discussion}

Serum AFP concentrations are often raised in gynaecological malignancies, such as EST of the ovary. In endometrial adenocarcinoma, however, production of AFP is extremely rare. To our knowledge only seven AFP producing endometrial tumours have been reported in the literature, four of which were EST at extragonadal sites. ${ }^{1-4}$ Ohta et $a l^{2}$ suggested that these tumours might have derived from fetal cells remaining after spontaneous abortion. Other authors ${ }^{134}$ suggested that the germ cells from which the EST originated had erroneously mi-

\begin{abstract}
years. On pelvic examination the uterus was enlarged but no adnexal masses were palpable. Biopsies of the endometrium were carried out and the histological diagnosis revealed poorly differentiated adenocarcinoma. A liver com-

A 62 year old Japanese woman was admitted to hospital in October 1993 with abnormal vaginal bleeding of one month's duration. Her medical history included one spontaneous
\end{abstract}


grated during embryogenesis and remained in the basal layer of the endometrium. One of the AFP producing endometrial tumours was a mixed mesodermal type and it was suggested that malignant transformation of müllerian epithelial and stromal cells had occurred independently following differentiation of primitive mesenchymal cells into epithelial and stromal components. ${ }^{5}$ Two other poorly differentiated AFP producing endometrial tumours were papillary adenocarcinomas. ${ }^{67}$ The latter three AFP producing tumours showed no evidence of yolk sac differentiation. Matsukuma and Tsukamoto ${ }^{6}$ suggested that the tumour they studied had originated from abnormally differentiated endometrial columnar cells which produced AFP. Kubo et al concluded that AFP producing tumours may arise from müllerian duct elements. The present case is an example of hepatoid adenocarcinoma of the uterus, because of the close resemblance of the neoplastic cells to hepatoid cells and because of the production of bile canaliculi-like structures, which reacted with the polyclonal but not the monoclonal antibody directed against CEA. ${ }^{8}$ Hepatoid adenocarcinomas have been reported in the genitourinary system, probably as a result of metaplastic or transdifferentiation processes. $^{9}$

AFP in the present case was diffusely localised to the cytoplasm. Reverse transcription polymerase chain reaction (RT-PCR) analysis of cDNA generated from the RNA present in the tumour cells using primers specific for AFP demonstrated the expression of AFP mRNA. AFP in the serum of our patient was purified by immunoaffinity chromatography and characterised. The results obtained on SDS polyacrylamide gel electrophoresis both before and after treatment with glycopeptidase $F$ were indistinguishable from those of hepatoma derived
AFP. This indicated that the AFP derived from the tumour was also composed of a single polypeptide chain with a molecular weight of 67000 and one $\mathrm{N}$-linked sugar chain (molecular weight 3000 ). The 10 amino acid $\mathrm{N}$ terminal sequence of the AFP derived from the endometrial adenocarcinoma was identical with that of the hepatoma derived form. AFP isoforms resulting from minor structural differences of carbohydrate moieties have been demonstrated by lectin affinity electrophoresis. ${ }^{10}$ Such analysis indicated that the isoform profile of this AFP is unique and distinct from the AFP derived from hepatomas, yolk sac tumours or cord serum. The detailed results of the biochemical characterisation of the AFP isolated from the present case will be reported elsewhere.

1 Pileri S, Martinelli G, Serra L, Bazzocchi F. Endodermal sinus tumors arising in the endometrium. Obstet Gynecol 1980;56:391-6.

2 Ohta M, Sakakibara K, Mizuno K, Kano T, Matsuzawa $\mathrm{K}$, Tomoda Y, et al. Successful treatment of primary endodermal sinus tumor of the endometrium. Gynecol Oncol 1988;31:357-64.

3 Clement P, Young R, Scully R. Extraovarian pelvic yolk sac tumors. Cancer 1988;62:620-6.

4 Joseph M, Fellows F, Hearn S. Primary endodermal sinus tumor of the endometrium. A clinicopathologic, immunocytochemical, and ultrastructural study. Cancer 1990;65: 297-302.

5 Kawagoe K. A case of mixed mesodermal tumor of the uterus with alpha-fetoprotein production. $\mathcal{f p}_{p} \mathfrak{f} \mathrm{Clin} \mathrm{Oncol}$ 1985;15:577-83.

6 Matsukuma K, Tsukamoto N. Alpha-fetoprotein producing endometrial adenocarcinoma: Report of a case. Gynecol Oncol 1988;29:370-7.

7 Kubo K, Lee G-H, Yamauchi K, Kitagawa T. Alpha-fetoprotein-producing papillary adenocarcinoma originating from a uterine body: A case report. Acta Pathol fpn 1991; 41:399-403.

$8 \mathrm{Ma}$ CK, Zarbo RJ, Frierson HF, Lee MW. Comparative immunohistochemical study of primary and metastatic

9 Sinard J, Macleay L, Melamed J. Hepatoid adenocarcinoma in the urinary bladder. Cancer 1994;73:1919-25.

10 Yamashita K, Taketa K, Nishi S, Fukushima K, Ohkura T. Sugar chains of human cord serum $\alpha$-fetoprotein: characteristics of $\mathrm{N}$-linked sugar chains of glycoproteins produced in human liver and hepatocellular carcinomas. Cancer Res 1993;53:2970-5.

\title{
Anti-GMl antibodies in polyneuropathies of unknown origin
}

\author{
J Finsterer, W Muellbacher, W M Halbmayer, M Fischer, B Mamoli
}

2. Neurological

Department,

Neurological Clinic

Rosenhügel, Vienna,

Austria

J Finsterer

W Muellbacher

B Mamoli

Central Laboratory, Municipal Hospital,

Vienna-Lainz, Austria

W M Halbmayer

M Fischer

Correspondence to: Dr J Finsterer, Kiedelgass 5, 1130 Vienna, Austria.

Accepted for publication 12 December 1995

\begin{abstract}
This study was undertaken to determine whether anti-GMI titres are raised in polyneuropathies of unknown origin and whether determination of these titres is useful for diagnosing these conditions. The study population comprised 20 controls (aged 36-88 years), 12 patients with polyneuropathies of known origin (aged 31-81 years) and 15 patients with polyneuropathies of unknown origin (aged 40-77 years). Antibody levels were measured using a commercial GMI enzyme linked immunosorbent assay kit (Buehlmann
\end{abstract}

Laboratories). Mean anti-GMI IgG and IgM antibody titres were not raised in patients with polyneuropathies of unknown origin. Anti-GMI IgG antibody titres were raised in one and GMI IgM antibody titres in none of the patients with polyneuropathies of unknown origin. In conclusion, GM1 antibody levels are rarely raised in polyneuropathies of unknown origin and probably play a minor role in the pathogenesis of these conditions. (f Clin Pathol 1996;49:422-425)

Keywords: ganglioside antibodies, polyneuropathies, motor neuron disease, neuroimmunology. 